www.jmscr.igmpublication.org

Index Copernicus Value: 79.54

ISSN (e)-2347-176x ISSN (p) 2455-0450

crossrefDOI: https://dx.doi.org/10.18535/jmscr/v7i2.119

\title{
A Scoring System to Predict Conversion of Laparoscopic Cholecystectomy to Open Cholecystectomy Preoperatively
}

\author{
Authors \\ Ravi Teja Puvvada ${ }^{1}$, Prabhakara Rao Yella ${ }^{2}$, Sushama Surapaneni $^{3}$ \\ ${ }^{1}$ Resident, Department of General Surgery, NRI Medical College and General Hospital, Chinakakani, India, \\ Email: raviteja1234@live.in \\ ${ }^{2,3}$ Professor, Department of General Surgery, NRI Medical College and General Hospital, Chinakakani, \\ India
}

\begin{abstract}
Introduction: Laparoscopic cholecystectomy is one of the most common laparoscopic procedures being performed by general surgeons all over the world. Preoperative prediction of the risk of conversion or difficulty of operation is an important aspect of planning laparoscopic surgery. The purpose of our retrospective study was to analyse various risk factors and to predict difficulty preoperatively by the use of a scoring system.

Materials: This retrospective study was conducted in the Department of General Surgery, NRI Medical College, Chinakakani. The parameters considered in the preoperative scoring method were age, sex, previous abdominal surgery, diabetes mellitus, history of pain in the right hypochondrium, history of fever, thickness of gall bladder wall, diameter of the common bile duct, size of the gall stone, pericholecystic collection, total leucocyte count, serum bilirubin, transaminases, ALP/GGT levels. A total of 51 patients were included in the study.

Results: Conversion rate from laparoscopic to open cholecystectomy was found to be $9.8 \%$. We found sensitivity and specificity of this preoperative scoring method to be $80 \%$ and $97.8 \%$ respectively.

Conclusion: With the help of accurate prediction, high risk patient may be counseled before the surgery regarding the probability of conversion. On the other hand, surgeons could be prepared for the possible complications that might arise and take necessary precautions in these high risk patients.
\end{abstract}

Keywords: laparoscopic cholecystectomy, open cholecystectomy, conversion, prediction.

\section{Introduction}

Laparoscopic cholecystectomy (LC) has become the procedure of choice for management of symptomatic gall stone disease. ${ }^{1}$ Approximately, 2$15 \%$ of attempted LC have to be converted to an open procedure due to various difficulties faced while performing the procedure. $^{2}$

Various clinical and ultrasonological parameters that may help to predict the difficulty level preoperatively were analyzed in the present study. Such prediction done preoperatively may help the patient as well as the surgeon in being better prepared for the intra-operative challenges.

With the help of accurate prediction, high risk patient may be counseled before the surgery regarding the probability of conversion. On the other hand, surgeons could be prepared for the possible complications that might arise and take necessary precautions in these high risk patients. 
Different scoring methodologies have been suggested from time to time using different criteria. The following study was planned keeping in mind this basic knowledge of the uncertainties encountered on the operating table that arise during laparoscopic cholecystectomy.

\section{Materials and Methods}

This retrospective study was conducted in the Department of General Surgery, NRI Medical College, Chinakakani. This study was commenced after obtaining approval from the ethical committee of the institution. A total of 51 patients were included in the study. A preoperative score was given to every patient on the basis of history, clinical examination and sonological findings (Table 1). Maximum score given was 15. Scores up to 7 were defined as easy and scores of 8 and above were defined as difficult.

Cases defined to be difficult were predicted to be converted to open surgery and those defined to be easy were predicted to be performed laparoscopically.

All the surgeries were performed by the consultants of the institution with equal experience in the field of laparoscopic surgery. Surgery was done using $\mathrm{CO} 2$ pneumoperitoneum and using standard two $5 \mathrm{~mm}$ and two $10 \mathrm{~mm}$ ports. Time was noted from first port site insertion till the last port closure.

\section{Results}

Of the 51 patients included in the study, 16 patients were male $(31.3 \%)$ and 35 were females $(68.7 \%)$. $26(50.9 \%)$ patients were younger than 50 years and $25(49.1 \%)$ were above 50 years of age (table 2 ).

Table 1- The scoring system

\begin{tabular}{|c|c|c|c|}
\hline \multicolumn{2}{|l|}{ CRITERIA } & SCORE & $\begin{array}{l}\text { TOTAL } \\
\text { SCORE }\end{array}$ \\
\hline \multirow{2}{*}{ AGE (IN YEARS) } & $<50$ & 0 & \multirow{2}{*}{1} \\
\hline & $>50$ & 1 & \\
\hline \multirow{2}{*}{ SEX } & FEMALE & 0 & \multirow{2}{*}{1} \\
\hline & MALE & 1 & \\
\hline \multirow{2}{*}{$\begin{array}{l}\text { DIABETES } \\
\text { MELLITUS }\end{array}$} & $\mathrm{NO}$ & 0 & \multirow{2}{*}{1} \\
\hline & YES & 1 & \\
\hline \multirow{2}{*}{$\begin{array}{ll}\text { HISTORY } & \text { OF } \\
\text { PREVIOUS } & \\
\text { SURGERIES } & \\
\end{array}$} & $\mathrm{NO}$ & 0 & \multirow[b]{2}{*}{1} \\
\hline & YES & 1 & \\
\hline
\end{tabular}

\begin{tabular}{|c|c|c|c|}
\hline \multirow{2}{*}{$\begin{array}{lr}\text { HISTORY OF PAIN } \\
\text { IN } & \text { RIGHT } \\
\text { HYPOCHONDRIUM } \\
\end{array}$} & NO & 0 & \multirow{2}{*}{1} \\
\hline & YES & 1 & \\
\hline \multirow{2}{*}{$\begin{array}{ll}\text { HISTORY } & \text { OF } \\
\text { FEVER } & \end{array}$} & NO & 0 & \multirow{2}{*}{1} \\
\hline & YES & 1 & \\
\hline \multirow{2}{*}{$\begin{array}{l}\text { TOTAL WHITE } \\
\text { CELL COUNT (IN } \\
\text { CELLS/CUMM) }\end{array}$} & $<11000$ & 0 & \multirow{2}{*}{1} \\
\hline & $>11000$ & 1 & \\
\hline \multirow{2}{*}{ SERUM BILIRUBIN } & NORMAL & 0 & \multirow{2}{*}{1} \\
\hline & ELEVATED & 1 & \\
\hline \multirow{2}{*}{$\begin{array}{l}\text { SERUM } \\
\text { TRANSAMINASES }\end{array}$} & NORMAL & 0 & \multirow{2}{*}{1} \\
\hline & ELEVATED & 1 & \\
\hline \multirow{2}{*}{ SERUM ALP/GGT } & NORMAL & 0 & \multirow{2}{*}{1} \\
\hline & ELEVATED & 1 & \\
\hline \multirow{2}{*}{$\begin{array}{l}\text { NUMBER } \\
\text { STONES }\end{array}$} & SINGLE & 0 & \multirow{2}{*}{1} \\
\hline & MULTIPLE & 1 & \\
\hline \multirow{2}{*}{$\begin{array}{l}\text { SIZE OF STONES } \\
(\text { IN CM) }\end{array}$} & $<1$ & 0 & \multirow{2}{*}{1} \\
\hline & $>1$ & 1 & \\
\hline \multirow{2}{*}{$\begin{array}{lr}\text { GB } & \text { WALL } \\
\text { THICKNESS } & \text { (IN } \\
\text { MM) } & \end{array}$} & $<3$ & 0 & \multirow{2}{*}{1} \\
\hline & $>3$ & 1 & \\
\hline \multirow{2}{*}{$\begin{array}{l}\text { CBD DIAMETER (IN } \\
\text { MM) }\end{array}$} & $<8$ & 0 & \multirow{2}{*}{1} \\
\hline & $>8$ & 1 & \\
\hline \multirow{2}{*}{$\begin{array}{l}\text { PERICHOLECYSTIC } \\
\text { FLUID }\end{array}$} & NO & 0 & \multirow{2}{*}{1} \\
\hline & YES & 1 & \\
\hline \multicolumn{3}{|c|}{ TOTAL SCORE } & 15 \\
\hline
\end{tabular}

Table 2 Age and sex distribution

\begin{tabular}{|c|c|c|c|}
\hline \multicolumn{2}{|c|}{ Criteria } & Frequency & Percentage \\
\hline \multirow{2}{*}{$\begin{array}{c}\text { Age (in } \\
\text { years) }\end{array}$} & $<50$ & 26 & 50.9 \\
\cline { 2 - 4 } & $>50$ & 25 & 49.1 \\
\hline \multirow{2}{*}{ Sex } & Male & 16 & 31.3 \\
\cline { 2 - 4 } & Female & 35 & 68.7 \\
\hline
\end{tabular}

Of the 51 cases, using the scoring system, 46 patients were defined as easy $(90.2 \%)$ and 5 were defined as difficult (9.8\%) (Table 3 ).

Table 3 no of easy and difficult cases

\begin{tabular}{|l|c|c|}
\hline Criteria & No of cases & percentage \\
\hline Easy & 46 & $90.2 \%$ \\
\hline Difficult & 5 & $9.8 \%$ \\
\hline
\end{tabular}

In 5 of the 51 cases, laparoscopy was converted to open surgery. (table 4). 
Table 4 number of cases converted to open surgery

\begin{tabular}{|l|c|c|}
\hline Procedure & No of cases & percentage \\
\hline $\begin{array}{l}\text { Converted to open } \\
\text { cholecystectomy }\end{array}$ & 5 & $9.8 \%$ \\
\hline Not converted & 46 & $90.2 \%$ \\
\hline
\end{tabular}

Of the 5 cases predicted to be difficult, 4 of them were converted to open surgery. For cases predicted to be easy, 45 of the 46 were completed laparoscopically and conversion to open surgery was not required (Table 5).

Table 5- procedure done

\begin{tabular}{|l|c|c|c|}
\hline Criteria & $\begin{array}{c}\text { No of } \\
\text { cases }\end{array}$ & $\begin{array}{c}\text { No of cases converted } \\
\text { to open }\end{array}$ & $\begin{array}{c}\text { Not } \\
\text { converted }\end{array}$ \\
\hline Difficult & 5 & 4 & 1 \\
\hline Easy & 46 & 1 & 45 \\
\hline
\end{tabular}

Sensitivity of this scoring system in predicting conversion to open surgery in cases defined to be difficult was $80 \%$.

Specificity of the system in predicting cases defined to be easy to be completed laparoscopically was $97.8 \%$.

\section{Discussion}

Laparoscopic cholecystectomy is one of the most commonly performed surgeries and is undergoing regular amendments with growing technology in order to make it safer, cosmetically acceptable, and cost effective.

Initially, the complication rate with LC was high but with technological advancement and increase in the expertise, it has now reached a remarkably low level at $2.0-6.0 \% .^{3}$

In our study laparoscopic cholecystectomy was performed in 51 patients and different predictive risk factors for difficult laparoscopic cholecystectomy were analyzed.

Old age, male sex, history of hospitalization, obesity, previous abdominal surgery, laboratory investigations, and ultrasonographic findings like gall bladder wall thickness, pericholecystic fluid collection were included as risk factors in this study.A scoring system was used in our study for prediction of conversion of laparoscopic to open cholecystectomy. Sensitivity and specificity of the scoring system were $80 \%$ and $97.8 \%$ respectively.
Approximately, 2-15\% of attempted LC has to be converted to an open procedure due to various difficulties faced while performing the procedure. ${ }^{2}$ In our study it was $9.8 \%$. The experience of the surgeon is an important factor that should be considered in for conversion.

Increasing age is associated with an increased probability of multiple attacks of cholecystitis and also increased frequency of upper abdominal surgeries. Therefore, there is increased incidence of fibrosis and adhesions in the hepatic hilum. Randhawa et al. ${ }^{3}$ found that age more than 50 years is associated with the same difficulties.

Supe etal. ${ }^{4}$ have proposed that male sex is associated with more intense inflammation or fibrosis resulting in denser adhesions thus a more difficult dissection.Pericholecystic collection was found to be a predictor of difficult LC. Upper abdominal scars (indicators of previous upper abdominal surgeries) may cause the formation of intraperitoneal adhesions that may lead to increased probability of injury and bleeding while placement of umbilical port. ${ }^{5}$

Majeski James in 1990, showed that a preoperative gallbladder ultrasound evaluation for symptomatic cholecystitis, which documents a thick gallbladder wall $(=3 \mathrm{~mm})$ with calculi, is a clinical warning for the laparoscopic surgeon of the potential for a difficult laparoscopic cholecystectomy procedure which may require conversion to an open cholecystectomy procedure. ${ }^{6}$

Adhesions are an important cause of difficulty in surgery and these cannot be assessed on routine ultrasonography (USG) done for cholelithiasis

Abnormal LFT and elevated amylase signify ongoing hepatitis, cholangitis and pancreatitis that pose difficulty in dissection due to oedema. Alphonat et al., ${ }^{2}$ and Kama et al., ${ }^{7}$ have demonstrated a similar association in their study. They have also obtained elevated total count as a predictor for difficulty.

One more factor is the presence of anatomical variation, making the identification of structures a demanding task. ${ }^{8}$ 


\section{Conclusion}

We may conclude that the scoring system used in our study is reliable and useful to predict difficult cases. However, the small sample size may be an impediment in attaining complete statistical validity. We propose large scale, multicentric studies to validate the scoring methodology and establish its efficacy.

\section{References}

1. V.H. Le, D.E. Smith, B.L. Johnson. Conversion of laparoscopic to open cholecystectomy in the current era of laparoscopic surgery. Am Surg, 78 (12) (2012 Dec), pp. 1392-1395.

2. Alponat A, Kum CK, Koh BC, Rajnakova A, Goh PM. Predictive factors for conversion of laparoscopic cholecystectomy. World J Surg. 1997;21:629-33.

3. Randhawa JS, Pujahari AK. Preoperative prediction of difficult lap chole: A scoring method. Indian J Surg. 2009;71(4):198-201. doi: 10.1007/s12262-009-0055-y.

4. Nachnani J, Supe A. Pre-operative prediction of difficult laparoscopic cholecystectomy using clinical and ultrasonographic parameters. Indian J Gastroenterol. 2005;24:16-8.

5. Botaitis S, Pitiakoudis $M$, Perente S, Tripsianis G, Polychronidis A, Simopoulos C. Laparoscopic cholecystectomy in acute cholecystitis: An analysis of the risk factors. S Afr J Surg. 2012;50:62. 64, 68.

6. J. MajeskiSignificance of preoperative ultrasound measurement of gallbladder wall thickness Am Surg, 73 (9) (2007), pp. 926929.

7. Kama NA, Kologlu M, Doganay M, Reis E, Atli M, Dolapci M. A risk score for conversion from laparoscopic to open cholecystectomy. Am J Surg. 2001;181:520-5.

8. Meshikhes AW, al-Dhurais S, Bhatia D, alKhatir N. Laparoscopic cholecystectomy: The Dammam Central Hospital experience. Int Surg. 1995;80:102-4. 